\title{
PERSAMAAN NILAI KORELASI INDEKS PLASTISITAS (PI) TANAH DENGAN CALIFORNIA BEARING RATIO (CBR) TANAH LEMPUNG PALANGKA RAYA
}

\author{
Noviyanthy Handayani ${ }^{1}$, Norseta Ajie Saputra ${ }^{2}$ \\ Program Studi Teknik Sipil, Fakultas Teknik, Universitas Muhammadiyah Palangkaraya \\ Email: civil@ umpalangkaraya.ac.id
}

\begin{abstract}
ABSTRAK
Selama ini untuk mendapatkan harga California Bearing Ratio (CBR) perencana akan melakukan uji lapangan dan atau uji laboratorium. Hal ini memakan waktu dan biaya yang relatif besar. Untuk itu diperlukan suatu hal praktis atau rumusan tentang hubungan antar parameter tanah sehingga perencana tidak perlu melakukan uji parameter tanah secara keseluruhan. Penelitian ini bertujuan untuk mendapatkan grafik atau korelasi Indeks Plastisitas (PI) dengan California Bearing Ratio (CBR) untuk tanah lempung wilayah Palangka Raya. Sampel tanah lempung diambil di 3 (tiga) lokasi yang ada di Kota Palangka Raya. Berdasarkan hasil pengujian pada beberapa sampel diperloleh nilai CBR paling terbesar pada sampel tanah dari desa Tangkiling yaitu mencapai nilai 6,56\%. Sedangkan nilai CBR terendah diperoleh dari desa Kereng Bengkirai yaitu 3,14\%. Untuk nilai PI diperoleh nilai terbesar pada desa Bukit Rawi yaitu terbesar yaitu 20,54\% dan nilai PI terkecil diperoleh pada desa Tangkiling sebesar 9,01\%. Secara umum dapat disimpulkan bahwa nilai CBR tanah lempung berbanding terbalik dengan nilai PI. Dimana diketahui bahwa semkin besar nilai CBR maka nilai PI semakin kecil begitu pula sebaliknya.Secara keseluruhan hasil korelasi nilai PI (plastisitas Indeks) terhadap CBR (California Bearing Ratio) memperoleh hasil korelasi menggunakan cara grafik linear $\mathrm{CBR}=-0,2983 \mathrm{PI}+8,9843$. Sedangkan nilai korelasi berdasarkan perhitungan analitis diperoleh $\mathrm{CBR}=-0,3006 \mathrm{X}+9,0190$. Pengujian ini menunjukan bahwa nilai korelasi ini memiliki hubungan sangat tinggi, jika dilihat dari patokan hasil korelasi $(\mathrm{R}=0,80-1,00)$. Hasil nilai korelasi menggunakan grafik regresi linear senilai $\mathrm{R}=0,8489$ dan menggunakan cara korelasi analitis senilai $\mathrm{R}=0,9283$. Jadi hasil akhir dari penelitian ini ialah mencari hubungan antara nilai PI terhadap nilai CBR. Maka untuk nilai $\mathrm{R}$ diambil nilai yang terkecil yaitu $R=0,8489$.
\end{abstract}

Kata kunci: Plastisitas Indeks, CBR, lempung, Korelasi

\section{ABSTRACT}

During this time to get the value of California Bearing Ratio (CBR) planners will conduct field tests and / or laboratory tests. This takes time and is relatively large. For this reason, it is needed a practical matter or formulation about the relationship between soil parameters so that planners do not need to test the overall soil parameters. This study aims to obtain a graph or correlation of Plasticity Index (PI) with California Bearing Ratio (CBR) for clay soils in the Palangka Raya region. Clay soil samples taken at 3 (three) locations in the City of Palangka Raya. Based on the results of tests on several samples obtained the largest CBR value in soil samples from Tangkiling village which reached a value of 6.56\%. While the lowest CBR value obtained from the village of Kereng Bengkirai is 3.14\%. For the PI value, the biggest value obtained in Bukit Rawi village is the largest, namely $20.54 \%$ and the smallest PI value obtained in Tangkiling village is $9.01 \%$. In general, it can be concluded that the CBR value of clay is inversely proportional to the value of PI. Wherein it is known that the greater the CBR value, the smaller the PI value and vice versa. The overall correlation results of the PI value (plasticity index) to the CBR (California Bearing Ratio) obtain the correlation results using the linear 
graph $C B R=-0.28383 P I+8,9843$. While the correlation value based on analytical calculations obtained $C B R=-0,3006 X+9,0190$. This test shows that the correlation value has a very high relationship, when viewed from the benchmark correlation results $(R=0.80-1.00)$. The results of the correlation value using linear regression graphs worth $R=0.8489$ and using analytical correlation methods worth $R=0.9283$. So the final result of this study is to look for a relationship between PI values and CBR values. Then for the value of $R$ is taken the smallest value that is $R=0.8489$.

Keywords: Plasticity Index, CBR, Clays, Correlation

\section{PENDAHULUAN}

Dalam konstruksi bangunan, nilai daya dukung $(\mathrm{CBR}=$ California Bearing Ratio $)$ memiliki pengaruh dalam perencanaan. Untuk mengetahui nilai CBR tentu harus dilakukan percobaanpercobaan di laboratorium maupun lapangan. Jika untuk setiap kali perencanaan harus dilakukan uji CBR, tentu akan memakan banyak waktu dan biaya. Oleh karena itu, diperlukan suatu rumusan untuk menyederhanakan parameter yang menyangkut nilai CBR. Salah satu parameter tanah yang bisa digunakan untuk mendapatkan harga CBR adalah indeks plastisitas tanah (PI). Dengan data-data hasil pengujian laboratorium yang akurat, maka dengan bantuan korelasi hubungan antara PI dengan CBR, maka bila nilai PI sudah bisa didapatkan, maka nilai dari CBR juga bisa didapatkan. Marwan dan Sundary (2012) menunjukkan hubungan antara PI dan CBR sebagai berikut:

1. $\quad$ CBR tidak terendam $=-0,990 \mathrm{PI}+28,79 ; \mathrm{R}^{2}$ $=0,868$ pada sampel tanah terganggu

2. $\mathrm{CBR}$ tidak terendam $=-0,464 \mathrm{PI}+10,60 ; \mathrm{R}^{2}$ $=0,728$ pada sampel tanah tidak terganggu.

3. CBR terendam $=-0,673 \mathrm{PI}+15,88 ; \mathrm{R}^{2}=$ 0,706 pada sampel tanah terganggu

4. CBR terendam $=-0,132 \mathrm{PI}+3,625 ; \mathrm{R}^{2}=$ 0,887 pada sampel tanah tidak terganggu.

Purnomo (2011) pada penelitiannya memperoleh hasil sebagai berikut:

1. Korelasi CBR dan PI adalah PI $=137,86-$ 6,792 CBR dan PI = 90,796 - 4,574 CBR.

2. Korelasi CBR dengan sudut geser tanah $(\Phi)$ yaitu : $\Phi=18,379+1,155$ CBR dan $\Phi=10,496+1,71 \mathrm{CBR}$.

3. Korelasi CBR dan kohesi $(\mathrm{C})$ yaitu : $\mathrm{C}=$ $0,165 \mathrm{CBR}-0,279$ dan $\mathrm{C}=0,174 \mathrm{CBR}-$ 0,5996 ,

4. Korelasi PI dengan sudut geser tanah $\Phi=$ $49,916-0,4 \mathrm{PI}$
Tetapi korelasi tersebut tidak berasal dari daerah Palangka Raya, yang tentu struktur dan sifat tanahnya kemungkinan besar berbeda. Sedangkan korelasi antara PI dengan CBR untuk daerah Palangka Raya belum ada. Kondisi inilah yang melatarbelakangi dilakukannya penelitian mengenai korelasi nilai PI dengan CBR untuk kondisi tanah di Palangka Raya.

Berdasarkan hal tersebut di atas, maka pada penelitian ini akan dilakukan penyelidikan agar didapat suatu korelasi antara nilai PI dengan CBR untuk tanah Palangka Raya. Dari hasil penelitian ini, diharapkan nantinya bila diketahui nilai PI maka nilai CBR dapat diketahui tanpa melakukan pengujian lagi di laboratorium.

Hal ini akan mampu mengurangi biaya dan waktu yang dikeluarkan untuk mendapatkan data CBR tanah di Palangka Raya.

\section{TINJAUAN PUSTAKA}

\section{California Bearing Ratio}

Uji CBR berasal dari Departemen Transportasi California tahun 1929. uji ini dimaksudkan untuk menentukan kelayakan suatu lapisan yanah yang akan digunakan sebagai subbase atau base course dalam konstruksi jalan raya. Sejak perang dunia kedua, U.S Army Corps of Engineers mengadaptasi uji ini untuk digunakan dalam konstruksi lapangan terbang.

Harga CBR adalah perbandingan antara beban penetrasi suatu bahan terhadap bahan standar dengan kedalaman dan kecepatan penetrasi yang sama.

Dalam bentuk rumus:

$\mathrm{CBR}=($ tegangan uji/tegangan baku $) \times 100 \%$.

Tabel harga dari tegangan baku adalah seperti pada Tabel 1. 
Tabel 1. Harga Tegangan Baku Untuk Setiap Penetrasi

\begin{tabular}{cccc}
\hline \multicolumn{2}{c}{ Penetrasi } & \multicolumn{2}{c}{ Satuan tegangan baku } \\
\hline Mm & inch & MPa & Psi \\
2.5 & 0.10 & 6.9 & 100 \\
5.0 & 0.20 & 10.3 & 1500 \\
7.5 & 0.30 & 13.0 & 1900 \\
10.0 & 0.40 & 16.0 & 2300 \\
12.7 & 0.50 & 18.0 & 2600 \\
\hline
\end{tabular}

Sumber: Bowles (1993)

Harga CBR digunakan untuk menilai kemampuan tanah, utamanya untuk digunakan sebagai base atau subbase di bawah perkerasan jalan atau lapangan terbang. Tabel 2 di bawah ini merupakan tipikal rating dari harga CBR.

Tabel 2. Klasifikasi Tanah Berdasarkan Harga CBR

\begin{tabular}{|c|c|c|c|c|}
\hline \multirow[b]{2}{*}{$\begin{array}{l}\text { CBR } \\
\text { No }\end{array}$} & \multirow[b]{2}{*}{$\begin{array}{l}\text { Tingkatan } \\
\text { Umum }\end{array}$} & \multirow[b]{2}{*}{ Kegunaan } & \multicolumn{2}{|c|}{ Klasifikasi } \\
\hline & & & Unified & $\begin{array}{c}\text { AASH } \\
\text { TO }\end{array}$ \\
\hline $0-3$ & $\begin{array}{l}\text { Very } \\
\text { poor }\end{array}$ & Subgrade & $\begin{array}{l}\mathrm{OH}, \mathrm{CH} \\
\text {,MH,O } \\
\mathrm{L}\end{array}$ & $\begin{array}{l}\text { A5,A6, } \\
\text { A7 }\end{array}$ \\
\hline $3-7$ & $\begin{array}{l}\text { Poor to } \\
\text { fair }\end{array}$ & Subgrade & $\begin{array}{l}\mathrm{OH}, \mathrm{CH} \\
\text {,MH,O } \\
\text { L }\end{array}$ & $\begin{array}{l}\text { A4,A5, } \\
\text { A6,A7 }\end{array}$ \\
\hline $7-20$ & Fair & Subbase & $\begin{array}{l}\text { OL,CL, } \\
\text { ML,SC } \\
\text {,SM,SP }\end{array}$ & $\begin{array}{l}\text { A2,A4, } \\
\text { A6,A7 }\end{array}$ \\
\hline $20-50$ & Good & $\begin{array}{l}\text { Base or } \\
\text { subbase }\end{array}$ & $\begin{array}{l}\text { GM,G } \\
\text { C,SW, } \\
\text { SM,SP, } \\
\text { GP }\end{array}$ & $\begin{array}{l}\mathrm{Ab}, \mathrm{A} 2- \\
5, \mathrm{~A} 3, \mathrm{~A} \\
2-6\end{array}$ \\
\hline$>50$ & Excellent & Base & & $\begin{array}{l}\text { A1a,A2 } \\
-4, A 3\end{array}$ \\
\hline
\end{tabular}

Sumber : Bowles ( 1993)

\section{Uji CBR Laboratorium}

Uji ini menggunakan alat penetrasi dengan kapasitas sekurang-kurangnya 4,45 ton dengan kecepatan penetrasi sebesar $1,25 \mathrm{~mm}$ per menit. Untuk uji CBR di laboratorium diperlukan uji pemadatan. Biasanya contoh tanah yang diambil untuk uji CBR di laboratorium adalah contoh tanah yang berada dalam kadar air optimum. Tetapi pemeriksaan CBR bisa saja dilakukan pada beberapa macam kadar air dan berat isi kering yang berbeda.

Kerugian dari penggunaan uji CBR laboratorium adalah :
Perlu waktu yang relatif lebih lama bila dibanding dengan uji langsung di lapangan, karena harus melalui prosedur - prosedur pengujian antara lain : penyaringan, Atterberg limit test, dan pemadatan.

Perlu biaya lebih diantaranya biaya pengambilan dan angkut contoh tanah ke laboratorium.

Contoh alat uji CBR laboratorium dapat dilihat pada Gambar 1 berikut

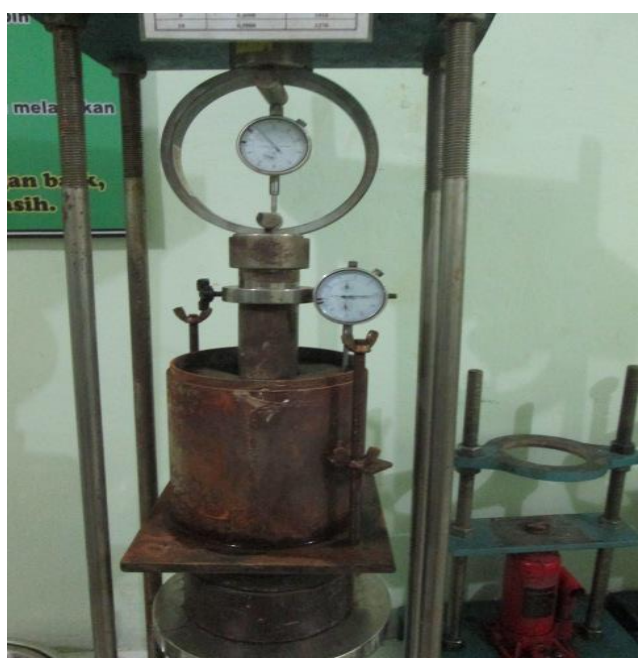

Gambar 1. Alat Uji CBR Laboratorium (Sumber dokumentasi pribadi)

\section{Uji CBR Lapangan}

Dibanding dengan uji laboratorium, uji CBR langsung di lapangan lebih menguntungkan dari segi waktu (data bisa didapat saat itu juga), dan tidak memerlukan pengambilan sampel tanah. Beberapa uji CBR yang biasa dilakukan di lapangan antara lain uji piston.

Uji ini antara lain menggunakan dongkrak CBR mekanis dengan kapasitas 10 ton, juga memerlukan sebuah truk atau kendaraan berat lainnya yang dibebani sesuai dengan kebutuhan dan dibawahnya dipasang sebuah dongkrak mekanis. Kerugian dari uji ini adalah penggunaan truk atau kendaraan sejenis yang membuat uji ini jadi kurang efisien.

\section{Indeks Plastisitas (PI)}

Umumnya tanah berbutir halus secara alamiah berada pada dalam kondisi plastis. Batas atas dan bawah dari rentang kadar air dimana tanah masih bersifat plastis berturut-turut disebut batas 
cair $(L L)$ dan batas plastis $(P L)$. Rentang kadar air itu sendiri didefenisikan sebagai indeks plastisitas $(P I)$, seperti pada persamaan :

$P I=L L-P L$

Indeks plastisitas $(P I)$ adalah selisih batas cair $(L L)$ dan batas plastis $(P L)$ dan tanah masih bersifat plastis.

Menurut Unified Soil Classification System (USCS) salah satu contoh tanah butir halus adalah tanah ini dibagi menjadi dua kelompok yaitu tanah butir halus yang sifat plastisnya rendah (LL < $50 \%)$ dan sifat plastisnya tinggi (LL > 50\%). Kemudian, simbol tanah butir halus ditetapkan dengan menggunakan plastisitas Casagrande didapat $\mathrm{CH}, \mathrm{MH}, \mathrm{OH}, \mathrm{CL}, \mathrm{ML}$ dan OL. Dengan data LL dan PI diplotkan dalam diagram, lalu dilihat secara analisis LL $<50 \%$ atau LL > 50\% selanjutnya dihitung PI batas $=0,73$ (LL-20), jika PI > PI batas berarti di atas garis A dan sebaliknya. Selain garis A, terdapat pula garis $U$ yang merupakan batas dari hubungan antara indek plastisitas dan batas cair untuk suatu tanah. Garis U mengikuti persamaan garis lurus $\mathrm{PI}=0,9(\mathrm{LL}-8)$ seperti Gambar 2. berikut

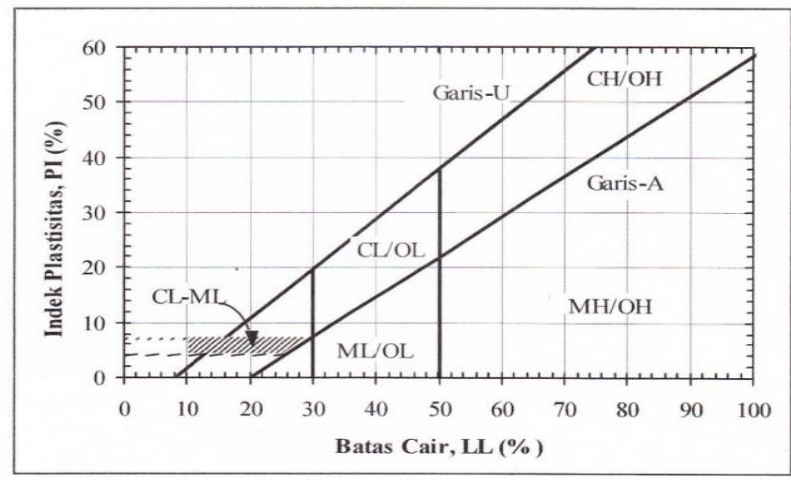

Gambar 2. Grafik Plastisitas untuk Klasifikasi Tanah USCS

(Sumber : Hardiyatmo,2010)

Kemudian menurut AASHTO (American Association of State Highway for Transportation Official bahwa tanah yang memiliki batas cair (PL) $>41 \%$ dan indeks plastisitas $(\mathrm{PI})>11 \%$ termasuk kelompok A-7-5/A-7-6. Kemudian, pada Gambar 2.2 dapat digunakan untuk memperoleh batas-batas antara batas cair (LL) dan plastisitas (PI) untuk kelompok A-4 sampai A-7 dan untuk sub kelompok dalam A-2. Dari Gambar tersebut, garis A dari Casagrande digambarkan bersama-sama dengan garis $\mathrm{U}$ yang dinyatakan oleh persamaan $\mathrm{PI}=0,9$ (PI-8). Garis U ini adalah garis batas atas dari hubungan LL dan PI untuk tanah-tanah di alam pada umumnya, Holtz dan Kovaes, 1981, (dalam Hardiyatmo, 2006)

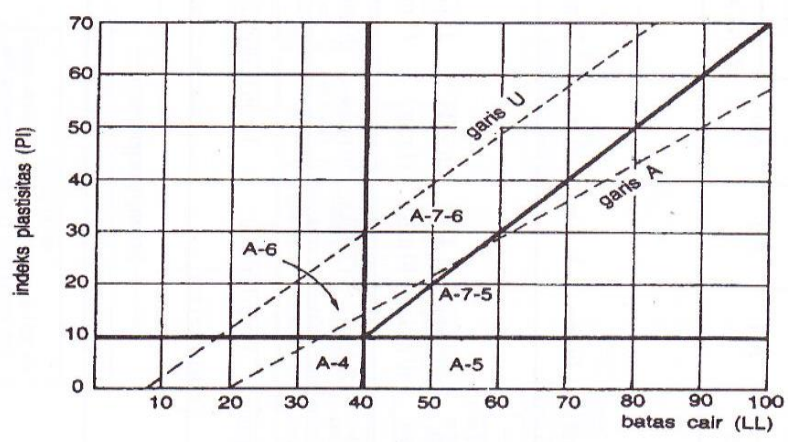

Gambar 3. Grafik Plastisitas Untuk Klasifikasi Tanah AASHTO

(Sumber : Hardiyatmo,2010)

Karena itu, Indeks Plastisistas menunjukkan sifat keplastisan tanah. Batasan mengenai indeks plastisitas, sifat, macam tanah dan kohesi seperti pada Tabel 3 berikut ini.

Tabel 3. Nilai Indeks Plastisitas dan Macam Tanah

\begin{tabular}{cccc}
\hline PI & Sifat & $\begin{array}{c}\text { Macam } \\
\text { tanah }\end{array}$ & Kohesi \\
\hline 0 & Non plastis & Pasir & $\begin{array}{c}\text { Non } \\
\text { kohesif } \\
\text { Kohesif } \\
\text { sebagian }\end{array}$ \\
77 & $\begin{array}{c}\text { Plastis } \\
\text { rendah }\end{array}$ & Lanau & Kohesif \\
$7-17$ & $\begin{array}{l}\text { Plastis } \\
\text { sedang }\end{array}$ & $\begin{array}{c}\text { Lempung } \\
\text { berlanau }\end{array}$ & Kohesif \\
& $\begin{array}{l}\text { Plastis } \\
\text { tinggi }\end{array}$ & Lempung & K17 \\
\hline
\end{tabular}

Sumber : Hardiyatmo (2006)

Untuk mengevaluasi tanah dalam kelompoknya digunakan indeks kelompok yang dihitung dengan rumus empiris seperti pada persamaan beriku dan pengujian yang digunakan adalah analisis saringan dan plastisitas.

$G I=(F-35)[0,2+0,005(L L-40)]+0,01(F-15)(P I-$

10)

Dimana:

$G I=$ Indeks kelompok (group indeks)

$F=$ Persen butiran lolos saringan no. 200

$L L=$ Batas cair

$P I=$ Indeks plastisitas 


\section{METODE PENELITIAN}

Pengambilan sampel tanah dilakukan di tiga titik di Kota Palangka Raya, Provinsi Kalimantan Tengah, yaitu Bukit Rawi, Kereng Bangkirai, dan Tangkiling. Tiap lokasi diambil sebanyak 3 sampel. Tiap sampel memiliki jarak rata-rata $50 \mathrm{~m}$ dan diambil menggunakan cangkul sebanyak 60 kilogram per sampel.

Selanjutnya sampel tanah lempung akan menjalani serangkaian uji. Uji-uji tersebut adalah pengujian distribusi ukuran butir, berat jenis, batas cair dan batas plastis, pemadatan standar, CBR, swelling dan UCS. Jumlah sampel tanah asli yang diperlukan untuk setiap uji adalah seperti pada Tabel 4 berikut.

Tabel 4. Jumlah Sampel Tanah Asli

\begin{tabular}{lcc}
\hline \multicolumn{1}{c}{ Pengujian } & $\begin{array}{c}\text { Jumlah } \\
\text { sampel/lokasi }\end{array}$ & $\begin{array}{c}\text { Total } \\
\text { sampel (3 } \\
\text { titik) }\end{array}$ \\
\hline $\begin{array}{l}\text { Disribusi ukuran } \\
\text { butir }\end{array}$ & 3 & 9 \\
Berat jenis & 3 & \\
Batas cair & 3 & 9 \\
Batas plastis & 3 & 9 \\
Pemadatan & 3 & 9 \\
CBR & 3 & 9 \\
UCS & 3 & 9 \\
\hline
\end{tabular}

\section{Bagan Alir Penelitian}

Proses penelitian di atas dijelaskan seperti bagan alir penelitian pada Gambar 4 berikut:

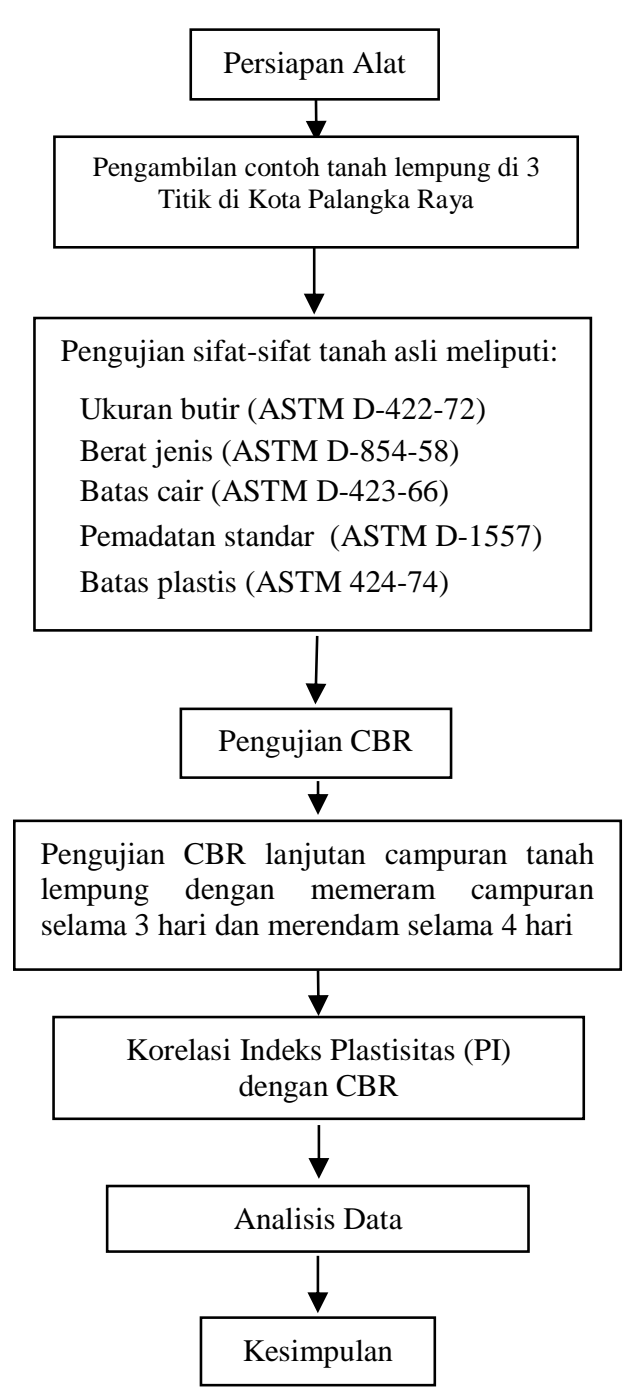

Gambar 4. Bagan Alir Penelitian

\section{HASIL DAN PEMBAHASAN}

\section{Hasil Penelitian}

Setelah dilakukan penelitian di Laboratorium Geoteknik Fakultas Teknik UM Palangkaraya, diperoleh karakteristik tanah lempung kota Palangka Raya berdasarkan masingmasing pengambilan sampel dapat dilihat pada Tabel 5 untuk mempermudah melakukan analisis maka dilakukan pengelompokan sampel tanah berdasarkan lokasi pengambilan sampel, antara lain:

1. Sampel A, adalah sampel tanah dari desa Tangkiling

2. Sampel B, adalah sampel tanah dari desa Bukit Rawi

3. Sampel C, adalah sampel tanah dari desa Kereng Bengkirai 
Persamaan Nilai Korelasi Indeks Plastisitas (PI)..., Noviyanthy Handayani ${ }^{(1)}$, Norseta Ajie Saputra ${ }^{(2)}$

Tabel 5. Karakteristik Tanah Lempung

\begin{tabular}{|c|c|c|c|c|}
\hline $\begin{array}{c}\text { Tipe } \\
\text { Pengujian }\end{array}$ & Sat. & $\begin{array}{c}\text { Sampe } \\
\text { I A }\end{array}$ & $\begin{array}{c}\text { Sampe } \\
\text { I B }\end{array}$ & $\begin{array}{l}\text { Sampe } \\
\text { I C }\end{array}$ \\
\hline $\begin{array}{l}\text { Kadar Air } \\
\text { Mula }\end{array}$ & $\%$ & 2,23 & 4,47 & 5,27 \\
\hline $\begin{array}{l}\text { Berat } \\
\text { Jenis }\end{array}$ & - & 2,60 & 2,68 & 2,62 \\
\hline $\begin{array}{l}\text { Batas Cair } \\
\text { (LL) }\end{array}$ & $\%$ & 33,20 & 47,00 & 61,00 \\
\hline $\begin{array}{l}\text { Batas } \\
\text { Plastis }\end{array}$ & $\%$ & 24,16 & 26,46 & 44,21 \\
\hline $\begin{array}{l}\text { Indeks } \\
\text { Plastisitas } \\
\text { (PI) }\end{array}$ & $\%$ & 9,04 & 20,54 & 16,79 \\
\hline $\begin{array}{l}\text { Lolos } \\
\text { Saringan } \\
\text { No.200 }\end{array}$ & $\%$ & 65,69 & 97,13 & 95,79 \\
\hline $\begin{array}{l}\text { Berat Isi } \\
\text { Kering } \\
\text { Maksimu } \\
\text { m }\end{array}$ & $\underset{3}{\mathrm{gr} / \mathrm{cm}}$ & 1,65 & 1,34 & 1,4205 \\
\hline $\begin{array}{l}\text { Kadar Air } \\
\text { Optimum }\end{array}$ & $\%$ & 19,00 & 30,50 & 27,20 \\
\hline $\begin{array}{l}\text { CBR } \\
100 \%\end{array}$ & $\%$ & 6,90 & 3,60 & 3,30 \\
\hline \multicolumn{4}{|c|}{ KLASIFIKASI TANAH } & 3,14 \\
\hline $\begin{array}{l}\text { Menurut } \\
\text { USCS }\end{array}$ & & ML & MH & MH \\
\hline $\begin{array}{l}\text { Menurut } \\
\text { AASHTO }\end{array}$ & & A-4 & A-7-6 & A-7-5 \\
\hline
\end{tabular}

Sumber: Hasil Penelitian (2019)

\section{Pembahasan}

\section{Kadar Air}

Pengujian kadar air dilakukan yaitu prsentase kadar air pada sampel tanah yang diambil dengan cara undisturbed (tidak terganggu).

Tabel 6. Hasil Pengujian Kadar Air

\begin{tabular}{clc}
\hline No & Lokasi Sampel & Kadar Air (\%) \\
\hline 1. & Desa Tangkiling & 2,23 \\
2. & Desa bukit Rawi & 4,47 \\
3. & Desa Kereng & 5,27 \\
& Bangkirai & \\
\hline
\end{tabular}

Sumber : Hasil Penelitian (2019)

\section{Berat jenis (Specific Gravity)}

Pengujian berat jenis dilakukan sebagai perbandingan berat volume butiran padat dengan volume air. Menurut Hary Christiady (1992) jenis tanah tanah lempung yang ada dapat diklasifikasikan berdasarkan nilai berat jenis tanah.

Tabel 7. Hasil Pengujian Berat Jenis

\begin{tabular}{clcc}
\hline No. & $\begin{array}{l}\text { Lokasi } \\
\text { Sampel }\end{array}$ & $\begin{array}{c}\text { Berat } \\
\text { jenis }\end{array}$ & Jenis Lempung \\
\hline 1. & $\begin{array}{l}\text { Desa } \\
\text { Tangkiling 1 }\end{array}$ & 2,60 & $\begin{array}{c}\text { Lempung/Lanau } \\
\text { Organik }\end{array}$ \\
2. & $\begin{array}{l}\text { Desa bukit } \\
\text { Rawi 2,68 }\end{array}$ & $\begin{array}{c}\text { Lempung/Lanau } \\
\text { Organik }\end{array}$ \\
3. & $\begin{array}{l}\text { Desa kereng } \\
\text { Bangkirai }\end{array}$ & 2,62 & $\begin{array}{c}\text { Lempung/Lanau } \\
\text { Organik }\end{array}$ \\
\hline
\end{tabular}

Sumber : Hasil Penelitian (2019)

\section{Batas-batas Atterberg}

Hasil dari pengujian batas-batas atterberg yaitu mencari nilai indeks plastisitas (PI) yang diperoleh dari pengujian selisih batas cair (LL) dan batas plastis (PL). Adapula hasil dari pengujian tersebut diantaranya sebagai berikut. Pada tabel 8 akan menunjukan hasil pengujian sebagai berikut.

Tabel 8. Hasil Pengujian Atterber Limit

\begin{tabular}{llccc}
\hline \multirow{2}{*}{ No } & \multirow{2}{*}{ Jenis Tanah } & \multicolumn{3}{c}{ Atterberg Limits } \\
& & LL & PL & PI \\
\hline 1. & Desa & 33,20 & 24,16 & 9,04 \\
& Tangkiling 1 & & & \\
2. & $\begin{array}{l}\text { Desa Bukit } \\
\text { Rawi }\end{array}$ & 47,00 & 26,46 & 20,54 \\
3. & $\begin{array}{l}\text { Desa Kereng } \\
\text { Bangkirai }\end{array}$ & 61,00 & 44,21 & 16,79 \\
\hline
\end{tabular}

Sumber : Hasil Penelitian (2019

\section{Pemadatan Standar Proctor}

Pemadatan yang dilakukan adalah pemadatan tanah asli. Parameter yang diperoleh dari pengujian menggunakan standar proctor adalah nilai berat isi kering maksimum $\left(\gamma \mathrm{d}_{\text {maks }}\right)$ dan kadar air optimum $\left(\mathrm{w}_{\mathrm{opt}}\right)$ seperti pada Tabel 9.

Tabel 9. Hasil Pemadatan Tanah Asli

\begin{tabular}{llcc}
\hline No & Jenis Tanah & \multicolumn{2}{c}{ Parameter Pemadatan } \\
Berat Isi Kering & $\begin{array}{c}\text { Wopt } \\
\text { Maks. }\left(\mathrm{g} / \mathrm{cm}^{3}\right)\end{array}$ & \multicolumn{1}{c}{$(\%)$} \\
\hline 1. & $\begin{array}{l}\text { Desa } \\
\text { Tangkiling }\end{array}$ & 1,65 & 19,00 \\
2. & $\begin{array}{l}\text { Desa bukit } \\
\text { Rawi }\end{array}$ & 1,34 & 30,50 \\
3. & $\begin{array}{l}\text { Desa kereng } \\
\text { Bangkirai }\end{array}$ & 1,42 & 27,20 \\
\hline
\end{tabular}

Sumber : Hasil Penelitian ,2019 


\section{California Bearing Ratio (CBR)}

Pengujian CBR laboratorium yang dilakukan adalah pengujian CBR yang bersifat rendaman (soaked.) Adapun sampel uji CBR kondisi harus direndam peram selama 1 hari dan dilakukan perendaman selama 5 hari. Hasil pengujian dapat dilihat pada tabel di bawah ini.

Tabel 10. Hasil Pengujian CBR

\begin{tabular}{llcc}
\hline \multirow{2}{*}{ No } & \multicolumn{2}{c}{ Jenis Tanah } & \multicolumn{2}{c}{ CBR Tanah (\%) } \\
& & $100 \%$ & $90 \%$ \\
\hline 1. & Desa Tangkiling 1 & 6,90 & 6,56 \\
2. & Desa Bukit Rawi 1 & 3,60 & 3,42 \\
3. & Desa Kereng & 3,30 & 3,14 \\
& Bangkirai & & \\
\hline
\end{tabular}

Sumber : Hasil Penelitian (2019)

\section{Hubungan Nilai Kadar Air, Plasitisitas Indeks (PI) dan California Bearing Ratio (CBR)}

Berdasarkan hasil pengujian yang telah dilaksanakan dapat dilakukan pengelompokan nilai Kadar Air, PI dan CBR berdasarkan lokasi pengambilan sampel dilapangan. Dalam melakukan perbandingan ini, untuk nilai CBR yang digunakan adalah nilai CBR Desain atau CBR $90 \%$. Hasil pengujian dituangkan pada tabel dibawah ini:

Tabel 11. Perbandingan Nilai PI dan CBR

\begin{tabular}{clccc}
\hline No & Jenis Tanah & $\begin{array}{c}\text { Kadar } \\
\text { Air }(\%)\end{array}$ & PI (\%) & CBR(\%) \\
\hline 1. & $\begin{array}{l}\text { Desa } \\
\text { Tangkiling } 1\end{array}$ & 2,23 & 9,04 & 6,56 \\
2. & $\begin{array}{l}\text { Desa Bukit } \\
\text { Rawi }\end{array}$ & 4,47 & 20,54 & 3,42 \\
3. & $\begin{array}{l}\text { Desa Kereng } \\
\text { Bangkirai }\end{array}$ & 5,27 & 16,79 & 3,14 \\
\hline
\end{tabular}

Berdasarkan nilai pada tabel perbandingan nilai PI dan CBR diatas dapat dituangkan dalam gambar kurva dibawah ini.

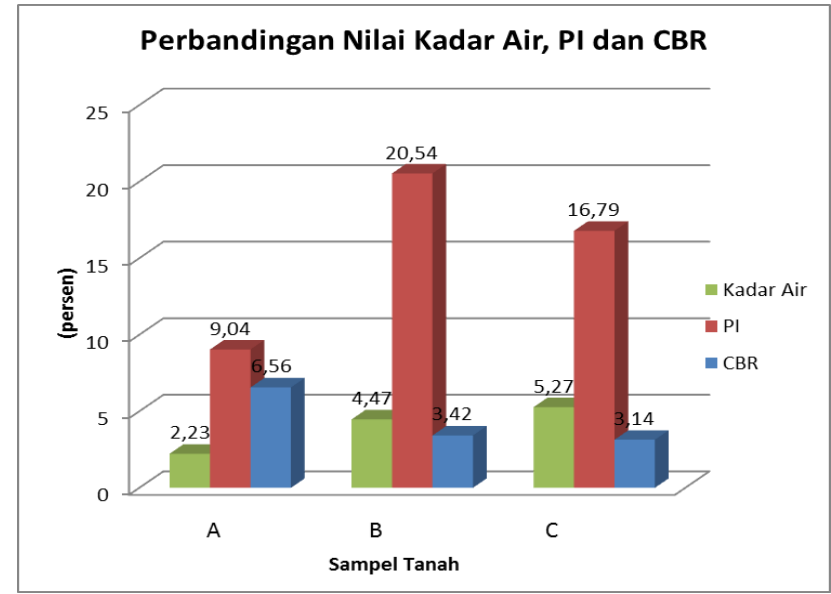

Gambar 5. Diagram Nilai Hasil Pengujian Kadar Air, PI dan CBR

(Hasil Penelitian, 2019)

Dari hasil pengujian pada Gambar 5 diatas menunjukan adanya peningkatan nilai Kadar Air berbanding terbalik dengan nilai PI. Sedangkan nilai CBR mengalami peningkatan sampai sampel kedua namun pada sampel ketiga CBR mengalami penurunan wlaupun tidak lebih kecil dari sampel pertama.

\section{Korelasi Nilai Plasitisitas Indeks (PI) dan California Bearing Ratio (CBR)}

Korelasi antar nilai Plastisitas Indeks (PI) dan CBR dapat dibuat dalam suatu hubungan yang dimuat dalam persamaan $\mathrm{Y}=\mathrm{a}+\mathrm{b} x$. Dalam pelaksanaannya hubungan korelasi ini dapat dilakukan dengan menggunakan metode grafik linear dan analitis persamaan linear. Pada gambar dibawah akan dilakukan korelasi nilai PI terhadap CBR dengan cara grafis.

Dilihat pada Gambar 6 grafik hasil korelasi hubungan nilai PI (Plastisitas Indeks) terhadap CBR (California Bearing Ratio) dari enam buah sampel tanah lempung yang dikorelasikan menggunakan regresi linier. Dari hasil tersebut dibuat dalam persaman linear dimana nilai CBR adalah Y dan nilai PI diwakili X, maka diperoleh persamaan linier $\mathrm{y}=-0,2983 x+8,9843$. Apabila dijabarkan berarti membentuk persamaan $\mathrm{CBR}=$ 0,2983 PI $+8,9843$. 


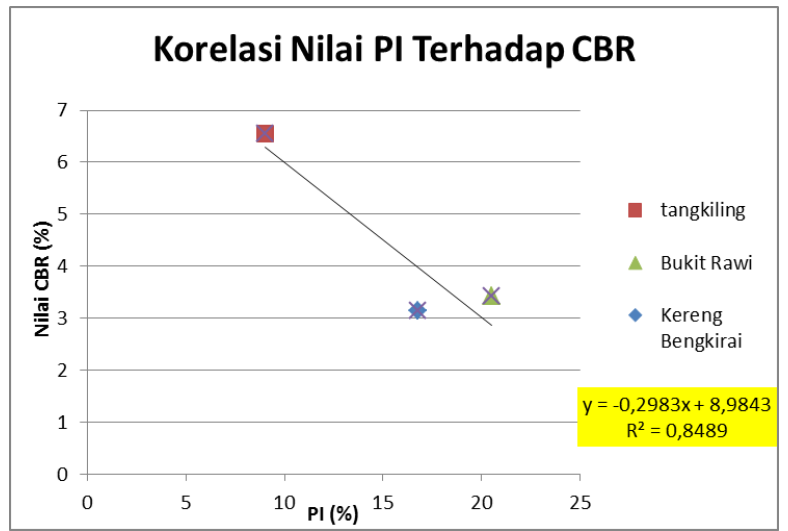

Gambar 6. Grafik Korelasi Nilai PI dan CBR

(Hasil Penelitian, 2019)

Sebagai contoh dalam penggunaan persamaan tersebut apabila diketahui nilai PI hasil pengujian diperoleh sebesar $12 \%$ maka nilai CBR tanah dapat ditentukan menggunakan persamaan, $\mathrm{CBR}=$ -
$0,2983(12)+8,9843$ atau diperoleh nilai CBR sebesar $5,4047 \%$. Sesuai dengan hasil pengujian yang dilakukan, terlihat bahwa nilai korelasi PI dan CBR menunjukkan, apabila nilai PI tanah tinggi maka nilai CBR tanah akan mengalami penurunan. Jadi hasil akhir dalam pengujian ini menyebutkan bahwa nilai korelasi ini memiliki hubungan sangat kuat, sesuai dengan patokan hasil perhitungan korelasi $\mathrm{R}=0,80-1,00$. Dalam pengujian ini didapatkan hasil akhir nilai $\mathrm{R}=$ 0,801 .

Sebagai perbandingan dilakukan perhitungan korelasi nilai PI terhadap CBR dengan menggunakan metode analitis yaitu menggunakan rumus hubungan linear mencari nilai korelasi.

Tabel 12. Hasil Perhitungan Korelasi Nilai PI dan CBR

\begin{tabular}{llrrrrr}
\hline No & \multicolumn{1}{c}{ Jenis Tanah } & PI $(\mathrm{X})$ & $\mathrm{CBR}(\mathrm{Y})$ & \multicolumn{1}{c}{$\mathrm{X}^{2}$} & \multicolumn{1}{c}{$\mathrm{Y}^{2}$} & \multicolumn{1}{c}{ X.Y } \\
\hline 1. & Desa Tangkiling 1 & 9,04 & 6,56 & 81,722 & 43,034 & 70,247 \\
2. & Desa Bukit Rawi & 20,54 & 3,42 & 421,892 & 11,696 & 52,721 \\
3. & Desa Kereng & & & & & \\
& Bangkirai & 16,79 & 3,14 & 281,904 & 9,860 & 182,270 \\
& Total & $\mathbf{4 6 , 3 7}$ & $\mathbf{1 3 , 1 2}$ & $\mathbf{7 8 5 , 5 1 7}$ & $\mathbf{6 4 , 5 9 0}$ & $\mathbf{7 0 , 2 4 7}$ \\
\hline
\end{tabular}

Sumber: Hasil Penelitian (2019)

Berdasarkan nilai pada Tabel 12 dapat dilakukan perhitungan unutk menentukan persamaan $\mathrm{y}=\mathrm{a} x+\mathrm{b}$. Parameter nilai $\mathrm{a}$ dan $\mathrm{b}$ dapat diperoleh dari rumus yang ada. Adapun penjabaran dari hasil perhitungan pada Tabel 4.10 sebagai berikut:

1. Nilai a diperoleh dari rumus $a=\frac{n \varepsilon x \cdot y-\varepsilon x \cdot \varepsilon y}{n \cdot(\varepsilon x)^{2}-\varepsilon x^{2}}$, dari rumus tersebut dieroleh nilai $a=-0,3006$

2. Nilai $b$ diperoleh berdasarkan penjabaran niai rumu $y=a x+b$, jadi nilai $b=y-a x$, dari rumus tersebut diperoleh nilai $b=9,0190$

3. Dari nilai parameter yang diperoleh dapat dibuat persamaan $\mathrm{y}=\mathrm{ax}+\mathrm{b}$ ataua $\mathrm{Y}=$ $0,3006 X+9,0190$. Apabila nilai dari sumbu $(\mathrm{x})=$ nilai PI dan sumbu $(\mathrm{y})=$ nilai $\mathrm{CBR}$, maka persamaan yang ada dapat disimpulkan CBR $=-0,3006$ PI + 9,0190.

4. Koefisien Korelasi yang diperoleh menggunakan rumus dibawah ini:

$$
r=\frac{n \Sigma x y-(\Sigma x)(\Sigma y)}{\sqrt{ }\left\{n \Sigma x^{2}-(\Sigma x)^{2}\right\}\left\{n \Sigma y^{2}-(\Sigma y)^{2}\right\}}
$$

Diperoleh nilai $r$ sebesar $-0,9283$, atau dalam penjelasanya memiliki korelasi sangat kuat antara $0,8-1$.

\section{PENUTUP}

\section{Kesimpulan}

Kesimpulan yang dapat diambil dari penelitian yang telah dilakukan adalah sebagai berikut:

1. Klasifikasi tanah lempung Desa Tangkiling, Desa Bukit Rawi dan Desa Kereng Bengkirai masing-masing termasuk ML dan MH. Atau dapat diartikan Desa Bukit Rawi dan Desa Bereng Bengkel memiliki klasifikasi tanah yang sama yaitu lanau/ lempung dengan plastisitas Tinggi . Sedangkan tanah desa Tangkiling memiliki klasifikasi lanau/ lempung degan Plastisitas Rendah.

2. Menurut AASHTO tanah lempung Desa Tangkiling, Desa Bukit Rawi dan Desa Kereng Bengkirai masing-masing termasuk kelompok A-4, A-7-6, dan A-7-5. Untuk tanah dari desa Bereng bengkel dan desa Bukit Rawi memilik tanah dengan sifat yang hampir sama namun yang membedakan adakah nilai tingkat plastisitasnya. Sedangkan 
tanah desa Tangkiling memiliki klasifikasi tanah yang lebih baik dengan plastisitas yang tidak terlalu tinggi dan nilai Liquid limit yang tidak terlalu tinggi.

3. Pada pengujian CBR nilai paling terbesar pada sampel tanah dari desa Tangkiling 1 yaitu mencapai nilai $6,56 \%$. Sedangkan nilai CBR terendah diperoleh dari desa Kereng Bengkirai yaitu $3,14 \%$.

4. Untuk nilai PI diperoleh nilai terbesar pada desa Bukit Rawi yaitu terbesar yaitu 20,54\% dan nilai PI terkecil diperoleh pada desa Tangkiling sebesar $9,01 \%$.

5. Secara umum dapat disimpulkan bahwa nilai CBR tanah lempung berbanding terbalik dengan nilai PI. Dimana diketahui bahwa semkin besar nilai CBR maka nilai PI semakin kecil begitu pula sebaliknya.

6. Secara keseluruhan hasil korelasi nilai PI (plastisitas Indeks) terhadap CBR (California Bearing Ratio) memperoleh hasil korelasi menggunakan cara grafik linear $\mathrm{CBR}=$ 0,2983 PI $+8,9843$. Sedangkan nilai korelasi berdasarkan perhitungan analitis diperoleh $\mathrm{CBR}=-0,3006 \mathrm{X}+9,0190$. Pengujian ini menunjukan bahwa nilai korelasi ini memiliki hubungan sangat tinggi, jika dilihat dari patokan hasil korelasi $(\mathrm{R}=0,90-1,00)$. Hasil nilai korelasi menggunakan grafik regresi linear senilai $R=0,8489$ dan menggunakan cara korelasi analitis senilai $\mathrm{R}=0,9283$.

7. Jadi hasil akhir dari penelitian ini ialah mencari hubungan antara nilai PI terhadap nilai CBR. Maka untuk nilai $\mathrm{R}$ diambil nilai yang terkecil yaitu $R=0,8489$.

\section{Saran}

Saran yang dapat diberikan dari hasil penelitian yang telah dilakukan ialah sebagai berikut:

1. Agar data penelitian lebih baik, sebaiknya dapat dilakukan penelitian yang akan datang, selanjutnya dengan memperbanyak jumlah sampel, bisa juga mencoba berbagai macam jenis tanah dan mencari hubungan lainnya yang masih kaitanya dengan pengujian sifat mekanis tanah atau hubungan sifat fisik tanah dan mekanis tanah lainnya.

2. Dalam penelitian dan pengujian dilaboratorium harus dilakukan dengan lebih teliti dan hati-hati agar tidak terdapat kesalahan.

\section{DAFTAR PUSTAKA}

Bowles, J.E, (1993). Sifat-sifat fisik dan Geoteknis Tanah. Erlangga, Jakarta

Hardiyatmo, HC, (2006). Mekanika Tanah 1, Edisi Keempat. Gajah Mada University Press. Yogyakarta.

Hardiyatmo, H.C, (2010), Stabilisasi Tanah Untuk Perkerasan Jalan. Gajah Mada University Press. Yogyakarta.

Marwan., Sundary, Devi (2012). Hubungan Nilai California Bearing Ratio Dengan Indeks Plastisitas Tanah Desa Neuheun Aceh Besar. Jurnal Teknik Sipil Universitas Syiah Kuala Volume 2 Nomor 1 September 2012.

Purnomo, Mego (2011). Korelasi Antara CBR, PI Dan Kuat Geser Tanah Lempung. Jurnal Teknik Sipil dan Perencanaan, Nomor 1 Volume 13 Januari 2011. 